\title{
CLINICAL AND URODYNAMIC ASSESSMENT OF ALPHA- ADRENOLYTIC THERAPY IN PATIENTS WITH NEUROGENIC BLADDER FUNCTION
}

\author{
By H. J. HACHEN \\ Spinal Injuries Centre, Geneva University Hospital, Switzerland
}

\begin{abstract}
The efficacy of alpha-adrenolytic treatment with oral phenoxybenzamine chloride (40 mg per day during three to four months) has been assessed both clinically and urodynamically among 249 patients with neurogenic bladder function. The results were significantly better in patients with autonomous $(n=95)$ than in the ones with automatic ( $\mathrm{n}=\mathrm{I} 54)$ bladders (urethral sphincter spasticity and detrusor sphincter dyssynergia dominating the clinical picture in the latter event). A further striking difference was noticed when the data were analysed with regard to the patient's age, a far better therapeutic response being regularly recorded in subjects below age 35 , while minimal and inconsistent improvements were observed in the older age group. No major side effects were encountered. Caution is however required in tetraplegics where phenoxybenzamine may aggravate orthostatic hypotension. On the other side the drug proves highly beneficial in these same patients in that it markedly lowers the incidence of dysreflexic states.
\end{abstract}

Key words: Alpha-adrenolytic therapy. Phenoxybenzamine chloride. Neurogenic bladder. Urodynamics.

\section{Introduction}

WITHIN the last decade the relatively new subspeciality of urodynamics has gained increasing recognition as a largely independent, major branch of urology. National and International Societies of Urodynamics have recently been founded in France, Italy, the United States and Japan. Most journals of urology regularly publish editorials and leading articles on urodynamic investigations. A personal market survey, carried out earlier this year in collaboration with eight European manufacturers of urodynamic equipment revealed an unexpectedly high increase of sales over the past five years. In fact, more and more practitioners feel a need to complete their standard X-ray units with integrated, TV-monitored systems, allowing for rapid diagnostic screening of such commonly encountered functional disorders as urge incontinence, chronic retention of neurogenic etiology, etc. (Thomas et al., 1975). This interest in the more functional pathology of the lower urinary tract clearly indicates that investigative urology has entered a new era within the last decade. This development has been made possible in view of the tremendous progress that was achieved in the late sixties in several closely affiliated scientific branches.

Modern technology, with its trend towards miniaturisation of electronic equipment nowadays allows for permanent, non-invasive monitoring of most body functions, with minimal inconvenience and hazards for the patient. The wellknown story behind the pocket calculator in many ways also applies to the currently

Author's address for reprints. H. J. Hachen, M.D., FRSH, FICA, Spinal Injuries Centre, 'Beau-Séjour', Geneva University Hospital, CH-I2 I I Geneva 4, Switzerland. 
designed urodynamic devices. As the market increases, prices are curbed, and equipment formerly reserved for major hospitals only is now available in many a practitioner's office.

Concomitantly our knowledge and understanding of the neuro-physiology of the lower urinary tract have greatly improved. Histochemical studies of the bladder and urethra have led to the identification of specific alpha- and betaadrenergic receptors (Elbadawi \& Schenk, I974; Edvardsen \& Seteklen, I968; Ek et al., I977; Khanna et al., 1976; Nergardh, I974; Pfau, I974; Raz et al., I973; Sundin et al., 1977). Stimulation of the alpha receptors causes a contraction, stimulation of the beta receptors on the contrary a relaxation of the smooth muscle fibres. A great many papers have also been published on the potent effect of cholinergic agents and cholinesterase inhibitors in the treatment of the hypotonic bladder and, inversely, of anticholinergic medication in the management of the hyperactive, non-inhibited bladder (Norlen, 1977; Sundin \& Dahlstroem, 1973; Taira, 1972). Over the past three years evidence has accumulated indicating that prostaglandins may play a significant and hitherto unrecognized part in a variety of dysuric states.

Drug research is turning out new substances at an ever increasing pace, which intervene as activators, some others as inhibitors of the detrusor, trigonum and striated sphincter. At present, more than thirty such agents are distributed through our hospital pharmacy. In patients having sustained spinal cord trauma, their judicious use offers new possibilities in the conservative management of the neurogenic bladder (Benson et al., I976; Bissada et al., 1977). Repeated urodynamic assessments, carried out under standard laboratory conditions, allow us to evaluate a patient's individual response to a given medication and to determine an optimal dose range.

\section{Neuropharmacology and Urodynamics}

In the routine assessment of the neurogenic bladder the following three tests have been found particularly useful when combined with cysto-sphincterometry (Hachen, I977).

\section{(a) Urecholine ® baclofen test}

In patients presenting a conus lesion and possibly a neurogenic bladder of the 'mixed' type, the recording of reflex detrusor contractions and of a significant rise in intravesical pressure within I 5 minutes after the subcutaneous injection of 2.5 $\mathrm{mg}$ of bethanechol chloride is compatible with the diagnosis of an upper motor neurone lesion. In our experience this test yields valuable information in the critical assessment of neurogenic bladders of the mixed type. Urecholine should never be administered repeatedly unless the absence of any infravesical obstacle, be it functional or anatomic, has been ascertained with micturition cysto-urethrography. In patients with detrusor-sphincter dyssynergia, the latter may be markedly increased during treatment with cholinergic agents and occasionally give rise to reflux formation (Diokno and Koppenhoefer, 1976).

\section{(b) Lioresal ® baclofen test}

In male patients with an upper motor neurone lesion and chronic retention due to excessive sphincter spasticity or detrusor-sphincter dyssynergia, the intra- 
venous injection of $20 \mathrm{mg}$ of baclofen significantly lowers the maximal urethral pressure. This test has proved reliable in the selection of candidates for sphincterotomy (Hachen \& Krucker, I977).

\section{(c) Regitine ${ }^{\circledR}$ test}

This test is primarily indicated in patients with an insufficient opening of the bladder outlet during micturition (Awad et al., 1976; Olsson et al., I977). If one observes a funnel-shaped widening of the trigonum (= positive answer) within Io minutes after the intravenous injection of 10 to $15 \mathrm{mg}$ of phentolamine mesylate (alpha-blocking agent), one may assume that the alpha-receptors at the trigonal level are a direct contributing factor responsible for the chronic retention. Over the past 8 years we have observed that this category of patient generally responds well to long-term oral alpha-adrenolytic treatment with phenoxybenzamine hydrochloride (Krane \& Olssen, I973; Mobley, 1976; Stockamp \& Schreiter, 1975).

\section{Clinical Trial with Phenoxybenzamine}

Between March I970 and February 1979, 249 male patients with an initially complete spinal cord lesion participated in a study on the efficacy and tolerance of phenoxybenzamine. One hundred and sixty-two patients were hospitalised, the remaining 87 were followed as outpatients. According to the results obtained during pretrial urodynamic evaluation, the patients were assigned either to a group with automatic (I 54 cases) or autonomous (95 cases) bladder function (Table I). In order to facilitate statistical analysis and avoid additional unknowns likely to distort the homogeneity of patient groups, all cases with mixed bladders or partial neurogenic involvement were excluded from the trial.

Since a pilot study had yielded particularly promising results in a group of teenagers, an observation also made by De Vogt and Van Der Sluis (I976), we carried out a further subdivision according to the patient's age; group A: I 5-35 years, and group B: 36-50 years.

In view of the possible hazards of a prolonged alpha-blockade among the elderly and expecting in this age group 'a priori' only a minimal therapeutic response, considering the prevalence of severe fibro-sclerotic changes at the bladder neck, we systematically excluded all patients above age 50 (Boreham et al., 1977; Haubensak et al., 1975).

Phenoxybenzamine hydrochloride was prescribed for periods ranging from 3 to 4 months, at a dosage of $20 \mathrm{mg}$ I2-hourly (Fig. I). The efficacy of the alphaadrenolytic medication was evaluated both clinically and urodynamically after approximately I month of treatment.

TABLE I

\begin{tabular}{lcccc}
\hline \multicolumn{1}{c}{$\begin{array}{c}\text { Type of } \\
\text { neurogenic bladder }\end{array}$} & $\begin{array}{c}\text { Number of } \\
\text { patients }\end{array}$ & \multicolumn{2}{c}{ Age } \\
& & $\begin{array}{c}\text { Group A } \\
\text { (15-35 years) }\end{array}$ & $\begin{array}{c}\text { Group B } \\
(36-50 \text { years })\end{array}$ \\
\hline Automatic (U.M.N. lesion) & I54 (62\%) & I I2 & 42 \\
Autonomous (L.M.N. lesion) & $95(38 \%)$ & 67 & 28 \\
& 249 & I79 & 70 \\
\hline
\end{tabular}




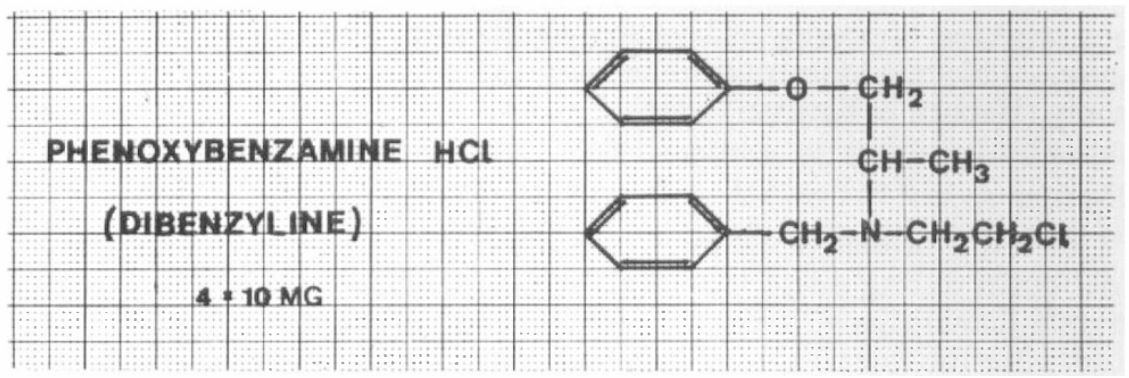

FIG. I

\section{Results}

(a) Autonomous neurogenic bladder function $(n=95)$

In this group we evaluated:

-the mean decrease of the post-micturition residual volume expressed in percent of the pretreatment values;

-the reduction of the trigonal pressure as calculated from the urethral pressure profiles (Brown \& Wickham, I969; Caine et al., 1975; Donker et al., 1972; Ghoneim et al., I975; Tanagho et al., 1969; Whitfield et al., 1976);

- the attenuation or disappearance of pre-existing autonomous waves;

- the changes in bladder capacity (volume increase by $\geqq 20$ per cent); and

- the incidence of subsequent bladder neck resections (failure of conservative treatment).

As indicated in Table II, the 67 patients in the younger age group (A) responded by a 43 per cent decrease in the residual volume and a 36 per cent decrease in bladder neck resistance $(\mathrm{p}<0.00 \mathrm{I}$; Student's $t$-test). Previously recorded autonomous waves disappeared in 33 per cent of the cases $(p<0.01)$ and an increase in bladder capacity of at least 20 per cent was observed in 54 per cent of the cases $(p<0.01)$. Bladder neck resections were carried out later on in Io per cent of the cases who had not responded sufficiently to phenoxybenzamine.

\section{TABLE II}

Clinical and urodynamic assessment of the alpha-adrenolytic action of phenoxybenzamine among 95 paraplegic patients with an autonomous neurogenic bladder function

(length of clinical trial: IO-I2 weeks; dosage: $40 \mathrm{mg}$ per day)

\begin{tabular}{|c|c|c|c|c|c|c|}
\hline & $\begin{array}{l}\text { Number } \\
\text { of } \\
\text { patients }\end{array}$ & $\begin{array}{c}\text { Decrease } \\
\text { resid. vol. } \\
\tilde{\mathrm{X}} \pm \mathrm{SD}\end{array}$ & $\begin{array}{c}\text { Decrease } \\
P \text { neck } \\
\tilde{\mathrm{X}} \pm \mathrm{SD}\end{array}$ & $\begin{array}{l}\text { Disappearance } \\
\text { autonomous } \\
\text { waves }\end{array}$ & $\begin{array}{l}\text { Increase } \\
\text { capacity } \\
\geqq 20 \%\end{array}$ & $\begin{array}{c}\text { Failure } \\
\text { (neck } \\
\text { resection) }\end{array}$ \\
\hline Group A & 67 & $43 \pm 7 \cdot 2 \%$ & $36 \pm 4 \cdot 2 \%$ & $\begin{array}{l}22 \text { cases } \\
33 \%\end{array}$ & $\begin{array}{l}36 \text { cases } \\
54 \%\end{array}$ & $\begin{array}{l}7 \text { cases } \\
\text { I0\% }\end{array}$ \\
\hline Group B & 28 & $19 \pm 5.5 \%$ & $9 \pm 4.4 \%$ & $\begin{array}{l}8 \text { cases } \\
29 \%\end{array}$ & $\begin{array}{l}8 \text { cases } \\
29 \%\end{array}$ & $\begin{array}{l}\text { I4 cases } \\
50 \%\end{array}$ \\
\hline Total & 95 & $35 \pm 5 \cdot 2 \%$ & $25 \pm 3.9 \%$ & $\begin{array}{l}30 \text { cases } \\
32 \%\end{array}$ & $\begin{array}{l}42 \text { cases } \\
44 \%\end{array}$ & $\begin{array}{l}\text { 2I cases } \\
22 \%\end{array}$ \\
\hline
\end{tabular}


In the older age group (B), both the clinical and urodynamic parameters indicated only slight modifications during alpha-adrenolytic treatment.

A I9 per cent decrease in residual volume and a 9 per cent drop in bladder neck resistance were both at the limit of statistical significance $(p<0.05)$. With regard to autonomous waves and bladder capacity, we registered barely a trend towards improvement ( $\mathrm{p}=$ n.s.).

Over-all assessment indicates that phenoxybenzamine failed to improve micturition in half of the patients assigned to group B. All these cases required endoscopic surgery within 6 months following our clinical trial.

\section{(b) Automatic neurogenic bladder function ( $n=154)$}

Following the initial state of spinal shock (Tulloch \& Rossier, I977), the large majority of patients with a complete upper motor neurone lesion develops some degree of detrusor sphincter dyssynergia (Jonas \& Tanagho, I975; Yalla et al., 1977) and spasticity of the striated urethral sphincter (Murdock et al., 1976). The co-existence of these two factors determines the degree of chronic retention which prevails during the early stage of bladder training. Combined radiocinematographic and urodynamic studies indicate that urethral sphincter spasticity is the single major cause responsible for chronic retention (Andersen \& Bradley, 1976). The trigonal component may, at times, intervene as contributing factor, the hypertonicity of the smooth muscle fibres preventing sufficient relaxation of the bladder outlet during detrusor contractions (Awad \& Downie, I977; Thorup Andersen et al., 1976; Tramoyeres Cases et al., 1972).

As indicated in Table III, 76 per cent of the patients in group A and 64 per cent in group $\mathrm{B}$ showed peak values above $125 \mathrm{cmH}_{2} \mathrm{O}$ in their urethral pressure profiles. Urodynamic and/or electromyographic evidence of detrusor-sphincter dyssynergia was detected in 84 per cent of the patients belonging to group $\mathrm{A}$ and in $8 \mathrm{I}$ per cent of the ones in group $\mathrm{B}$.

Among the I54 patients with an upper motor neurone lesion, treatment with phenoxybenzamine hydrochloride yielded the following results:

- I 7 per cent of the cases in group A and 4 per cent only in group B presented a funnel-shaped enlargement of the proximal urethra on video-recorded micturition cysto-urethrography (Figs $2 \mathrm{a}, 2 \mathrm{~b}$ ).

-A reduction of postmicturition volumes to $75 \mathrm{ml}$ or below was observed in 19 per cent of the cases belonging to the younger (A) and in 5 per cent of the ones in the older age group (B). Statistical analysis reveals that these results are at the limit of significance for the subgroup A, and not significant in the subgroup B.

These rather disappointing results are partly compensated by the fact that in four among eleven patients with a massive vesico-renal reflux and marked ureteral dilation (known to exist since 3 to 9 months prior to phenoxybenzamine treatment), this reflux disappeared during alpha-adrenolytic treatment. Similar findings have been reported by Stockamp (1975).

\section{SUMMARY}

Phenoxybenzamine hydrochloride, a selective inhibitor of alpha-adrenergic receptors, has been shown to be a valuable pharmaceutic agent in the conservative management of patients with an autonomous neurogenic bladder function. The author analyses the results obtained in a group of 95 patients treated for periods of 


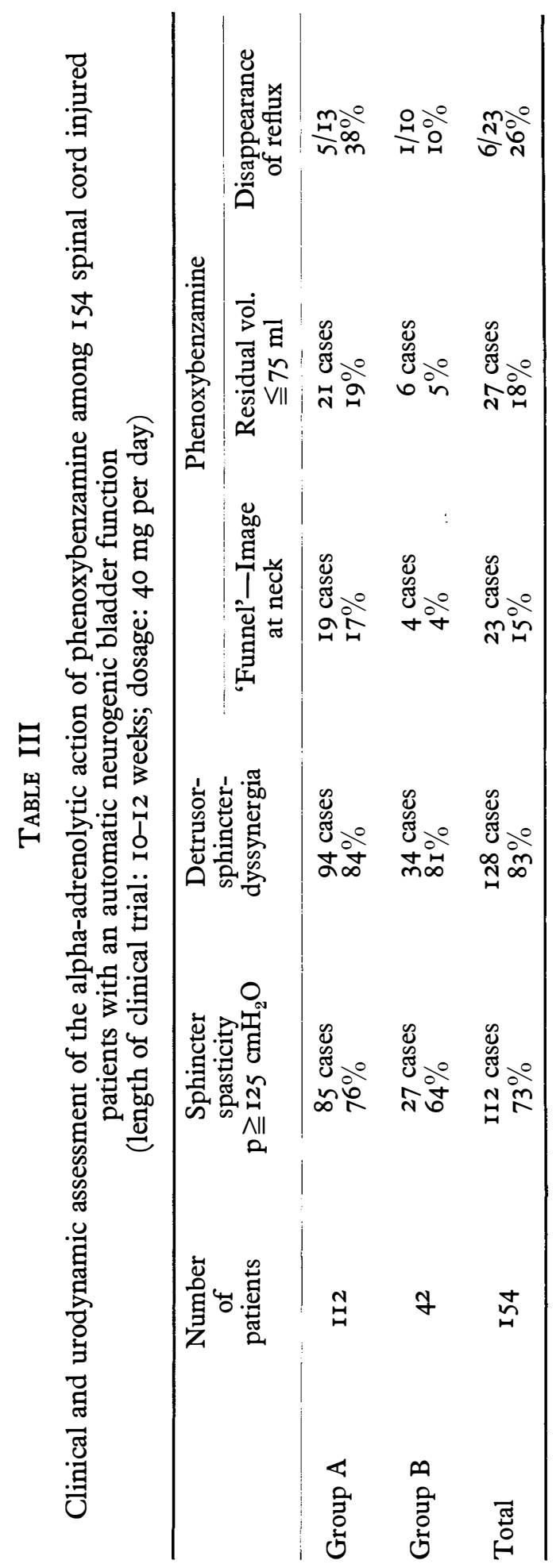



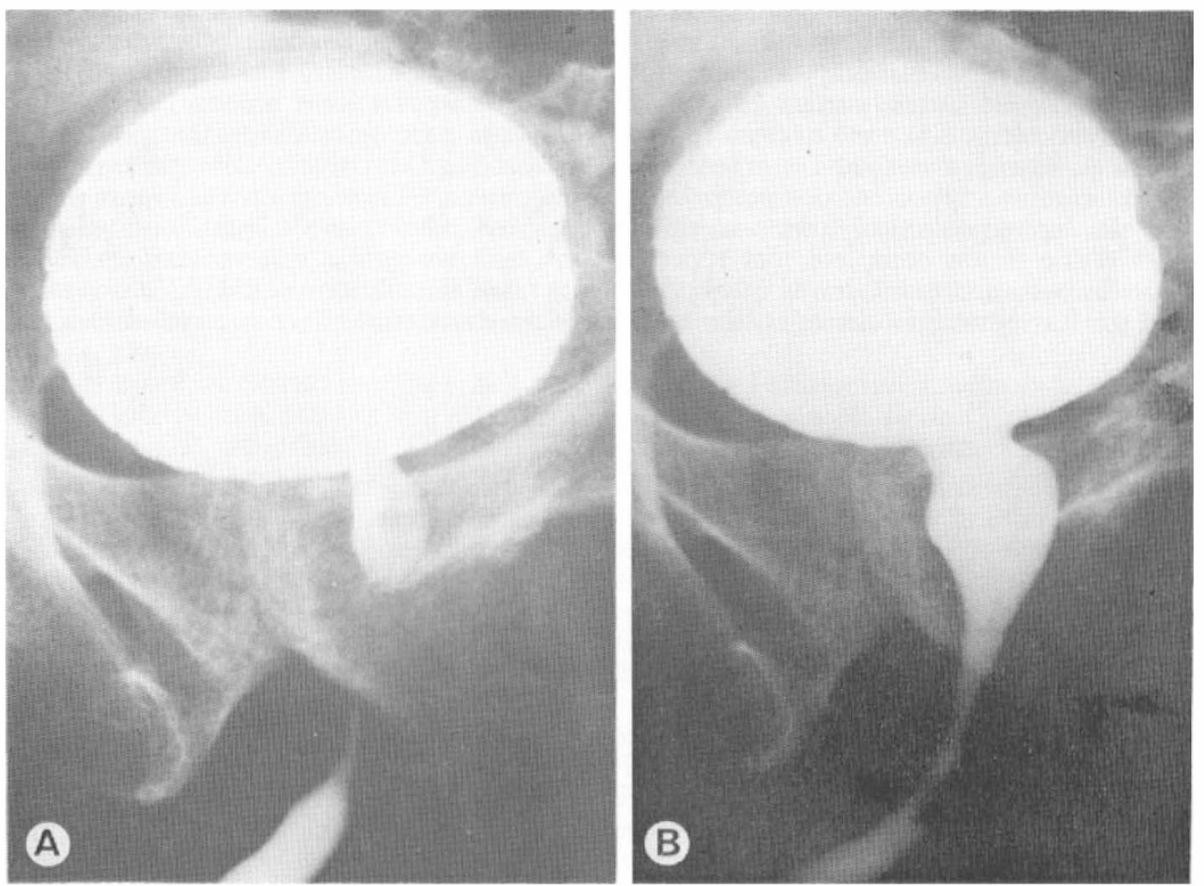

FIG. 2

3 to 4 months at a daily dosage of $40 \mathrm{mg}$. Serial urodynamic recordings indicate that significant improvement of micturition may be observed in the young patients, particularly in teenagers. Subjects above the age of 50 usually respond poorly to alpha-adrenolytic treatment, since their bladder outlet shows various degrees of fibro-sclerotic infiltration.

In a second patient group comprising I 54 cases with an automatic neurogenic bladder, the beneficial effect of phenoxybenzamine (reduction of outlet resistance) was largely masked by severe urethral spasticity and vesico-urethral dyssynergia.

No major side effects were observed during prolonged alpha-blockade. In eight tetraplegics with orthostatic hypotension the dose range had to be maintained initially at $20 \mathrm{mg}$ daily before being gradually increased to a therapeutically active level. Retrograde ejaculation has been reported as being a major complication in patients receiving an alpha-blocker. In patients with complete spinal cord lesions this finding is of lesser relevance, since the mechanism of ejaculation is already altered due to damage of the spinal cord and absence of co-ordinated reflex activity.

\section{RÉSUMÉ}

La phénoxybenzamine, qui agit de façon sélective sur les alpha-récepteurs, s'est avérée être fort utile dans la rééducation des vessies neurogènes du type autonome. L'auteur rapporte son expérience dans un groupe de 95 patients traités pendant 3-4 mois à la posologie journalière de $40 \mathrm{mg}$. A l'aide d'examens urodynamiques (cysto-sphinctérométrie et enregistrement du profil urétral), il a été possible de démontrer que les meilleurs résultats sont généralement rencontrés chez les sujets jeunes, âgés de moins de 35 ans. Chez l'individu au-delà de la cinquantaine, l'infiltration fibro-scléreuse au niveau trigonal empêche un relâchement efficace de la musculature lisse sous l'effet du traitement alpha-adrénolytique.

Dans un deuxième groupe de I54 patients présentant une vessie du type automatique, 
l'effet favorable de la phénoxybenzamine au niveau de l'urètre proximal fut largement dominé par une spasticité marquée du sphincter strié, ainsi que par une dyssynergie vésicosphinctérienne. L'effet thérapeutique a donc été faible ou nul dans cette série de patients. La tolérance a été satisfaisante. Chez 8 tétraplégiques, présentant un syndrome d'hypotension orthostatique, il a été nécessaire de maintenir la posologie initialement pendant 2-3 semaines à $20 \mathrm{mg}$ avant de l'augmenter progressivement au niveau thérapeutique actif. Plusieurs auteurs rapportent des perturbations majeures de l'éjaculation chez leurs patients traités de façon prolongée avec un alpha-bloqueur. Chez les traumatisés médullaires atteints d'une lésion complète, ces répercussions néfastes sur la sphère sexuelle sont de moindre importance, étant donné que le mécanisme de l'éjaculation est d'emblée sévèrement touché par l'atteinte médullaire et le manque de coordination de l'activité réflexe.

\section{ZUSAMMENFASSUNG}

Phenoxybenzamin, ein selektiver Alpha-Rezeptoren-Blocker, hat sich bei der konservativen Behandlung autonomer neurogener Blasenstörungen gut bewährt. Der Autor berichtet über seine urodynamisch und klinisch erfassten Resultate bei 95 Patienten, welche während 3 bis 4 Monaten täglich $40 \mathrm{mg}$ des aktiven Wirkstoffes erhielten. An Hand von Blasendruckmessungen und Aufzeichnungen des Urethralprofils wird gezeigt, dass die besten Resultate in der Altersklasse bis $35 \mathrm{zu}$ beobachten sind. Bei den über fünfzig Jahre alten Patienten verhindern die fibrosklerotischen Gewebeveränderungen am Blasenhals eine positive Auswirkung der Alpha-Blockade.

In einer zweiten Gruppe von I 54 Patienten mit einer neurogenen Reflexblase wurde die Wirkung des Phenoxybenzamins am Blasenhals weitergehend durch eine stark ausgeprägte Sphinkterspastizität und Detrusor-Sphinkterdyssynergie überschattet. Die Miktions-störungen wurden somit in dieser Gruppe nur schwach oder überhaupt nicht gebessert. Nebenwirkungen wurden nur vereinzelt festgestellt. Bei acht Tetraplegiker, welche alle eine Tendenz zu einem orthostatischen Syndrom aufwiesen, musste die Dosierung aufänglich während zwei bis drei Wochen bei $20 \mathrm{mg}$ beibehalten werden, bis es anschliessend möglich wurde, langsam bis zur therapeutisch aktiven Dosierung anzusteigen. Verschiedene Autoren berichten über Ejakulationsstörungen bei den mit Phenoxybenzamin behandelten Patienten. Bei Querschnittsgelähmten mit einem totalen neurologischen Ausfall sind die betreffenden Nebenwirkungen auf die Sexualsphäre von geringerer Bedeutung, da der Ejakulationsmechanismus ja bereits infolge der Rückenmarksschädigung und der gestörten Reflexkoordination stark beeinträchtigt ist.

\section{REFERENCES}

Andersen, J. T. \& BRAdley, W. E. (1976). The syndrome of detrusor-sphincter dyssynergia. f. Urol., 116, 493.

Awad, S. A., Bruce, A. W., CARro-Ciampi, G., Downie, J. W., Lin, M. \& Marks, G. S. (1974). Distribution of alpha- and beta-adrenoceptors in human urinary bladder. Brit. F. Pharmacol., 50, 525.

Awad, S. A., Downie, J. W., Lywood, D. W., Young, R. A. \& Jarzylo, S. V. (1976). Sympathetic activity in the proximal urethra in patients with urinary obstruction. $\mathcal{F}$. Urol., I15, 545 .

AWAD, S. A. \& Downie, J. W. (1977). Sympathetic dyssynergia in the region of the external sphincter; a possible source of lower urinary tract obstruction. f. Urol., 118, 636.

Benson, G. S., Wein, A. J., Ragzer, D. M. \& Corriere, J. N. (1976). Adrenergic and cholinergic stimulation and blockade of the human bladder base. F. Urol., 116, 174.

Bissada, N. K., FinkbeineR, A. E. \& WeLCH, L. T. (1977). Lower urinary tract pharmacology. III. Neuropharmacologic basis for lower urinary tract dynamics. Urol., 9, 357.

Boreham, P. F., Braithwaite, P., Milewski, P. \& Pearson, H. (1977). Alpha-adrenergic blockers in prostatism. Br. F. Surg., 64, 756.

Brown, M. \& Wickham, E. A. (I969). The urethral pressure profile. Brit. f. Urol., 4I, 2 II.

CaINe, M. \& Raz, S. (1975). Some clinical implications of adrenergic receptors in the urinary tract. Arch. Surg., II0, 247.

Caine, M., RaZ, S. \& ZeigleR, M. (I975). Adrenergic and cholinergic receptors in the human prostate, prostatic capsule and bladder neck. Brit. F. Urol., 47, 193. 
Caine, M., Pfau, A. \& Perlberg, S. (1976). The use of alpha-adrenergic blockers in benign prostatic obstruction. Br. F. Urol., 48, 255.

De Vogt, H. J. \& VAN DeR SLUis, C. (I976). Preliminary evaluation of alpha-adrenergic blocking agents in children with neurogenic bladder due to myelomeningocele. Develop. Med. Child Neurol., 18, 82.

Diokno, A. C., KofF, S. A. \& BENDER, L. F. (1974). Periurethral striated muscle activity in neurogenic bladder dysfunction. F. Urol., II3, 743.

Diokno, A. C. \& KoppenhoEFER, R. (1976). Bethanechol chloride in neurogenic bladder dysfunction. Urol., 8, 455 .

Donker, P. J., Ivanovici, F. \& NoACH, E. L. (I972). Analysis of the urethral pressure profile by means of electromyography and the administration of drugs. Brit. $\mathcal{F}$. Urol., 44, 180 .

EDVARDSEN, P. \& SETEKLEN, J. (1968). Distribution of adrenergic receptors in the urinary bladder of cats, rabbits and guinea-pigs. Acta Pharmacol. Toxicol., 26, 437.

Ek, A., Alm, P., ANDERSSON, K.-E. \& PERSSON, C. G. A. (I977). Adrenoceptor and cholinoceptor mediated responses of the isolated human urethra. Scand. F. Urol. Nephrol., II, 97 .

ElbadAwI, A. \& Schenk, E. A. (I974). A new theory of the innervation of bladder musculature. Part 4: Innervation of the vesico-urethral junction and external urethral sphincter. F. Urol., III, 613.

Ghoneim, M. A., Rottembourg, J. L., Fretin, J. \& Susset, J. G. (I975). Urethral pressure profile. Standardization of technique and study of reproducibility. Urol., 5, 632.

HACHEN, H. J. (1977). Diagnostic et traitement des dysfonctionnements vésicosphinctériens d'origine neurogène. Folia Chemother. Roche, I5, I.

HACHEN, H. J. \& KRUCKER, V. (I977). Clinical and laboratory assessment of the efficacy of baclofen (Lioresal $®$ ) on urethral sphincter spasticity in patients with traumatic paraplegia. Europ. Urol., 3, 237.

HaUbensak, E., SchindleR, E. \& RothaAR, J. (1975). Dependence of resting urethral pressure on age and sex of healthy subjects and on technical details. Urol. Int., 30, 29.

Jonas, U. \& TANAGHo, E. A. (1975). Studies on vesico-urethral reflexes. I. Urethral sphincteric responses to detrusor stretch. Invest. Urol., 12, 357.

Khanna, O. P., Heber, D. \& Gonick, P. (1975). Cholinergic and adrenergic neuroreceptors in urinary tract of female dogs. Evaluation of function with pharmacodynamics. Urol., 5, $6 \mathrm{I} 6$.

KhanNA, O. P. (1976). Disorders of micturition. Neuropharmacologic basis and results of drug therapy. Urol., 8, $3 \mathrm{I} 6$.

KLEEMAN, F. J. (1970). The physiology of the internal urinary sphincter. F. Urol., ro4, 549.

KRANE, R. J. \& Olssen, C. A. (I973). Phenoxybenzamine in neurogenic bladder dysfunction. F. Urol., II0, 653 .

McGuire, E. J., WaGner, F. M. \& Weiss, R. M. (1976). Treatment of autonomic dysreflexia with phenoxybenzamine. F. Urol., I15, 53.

Mobley, D. F. (1976). Phenoxybenzamine in the management of neurogenic vesical dysfunction. f. Urol., I16, 737.

Murdock, M. M., SAX, D. \& KRANE, R. J. (1976). Use of dantrolene sodium in external sphincter spasm. Urol., 8, I33.

Nergardh, A. \& Boreus, L. O. (1972). Autonomic receptor function in the lower urinary tract of man and cat. Scand. F. Urol. Nephrol., 6, 32.

NeRgardH, A. (1974). The functional role of adrenergic receptors in the outlet region of the urinary bladder. Scand. F. Urol. Nephrol., 8, Ioo.

NoRLEN, L. (1977). Effects on the urinary bladder and urethra of different pharmacological treatments. Scand. F. Urol. Nephrol., II, 7.

NyBERG-HANSEN, R. (1966). Innervation and nervous control of the urinary bladder. Acta Neurol. Scand., $42,7$.

Olsson, C. A., Siroky, M. B. \& KRANE, R. J. (I977). The phentolamine test in neurogenic bladder dysfunction. F. Urol., I17, 481.

Pfau, A. (1974). The influence of the adrenergic system on the lower urinary tract. Urol. Digest, 13, I5.

Raz, S. \& CAINE, M. (1972). Adrenergic receptors in the female canine urethra. Invest. Urol., 9, 319. $18 / 4-B$ 
RaZ, S., Ziegler, M. \& Caine, M. (I973). The effect of progesterone on the adrenergic receptors of the urethra. Br. F. Urol., 45, I3I.

Refsum, H. \& LANDMARK, K. (1973). Competitive antagonism between phenoxybenzamine and acetylcholine in isolated rat atria. Acta Pharmacol. Toxicol., 33, I7.

Rohner, T. J., Raezer, D. M., Wein, A. J. \& Schoenberg, H. W. (I97I). Contractile responses of dog bladder neck muscle to adrenergic drugs. F. Urol., I05, 657.

Shessel, F. W., Carrion, H. M. \& Politano, V. A. (1978). Phenoxybenzamine and sweating in the spinal cord injury patient. F. Urol., r2o, 60.

Stockamp, K. (I975). Treatment with phenoxybenzamine of upper urinary tract complications caused by infravesical obstruction. F. Urol., 113, I28.

STOCKAMP, K. \& SCHREITER, F. (I975). Alpha-adrenolytic treatment of the congenital neuropathic bladder. Urol. Int., 30, 33.

Sundin, T. \& DAHLSTROEM, A. (1973). The sympathetic innervation of the urinary bladder and urethra in the normal state and after parasympathetic denervation at the spinal root level. Scand. F. Urol. Nephrol., 7, I3I.

Sundin, T., Dahlstroem, A., Norlen, L. \& Svedmyr, N. (1977). The sympathetic innervation and adrenoreceptor function of the human lower urinary tract in the normal state and after parasympathetic denervation. Invest. Urol., 14, 322.

TAIRA, N. (1972). The autonomic pharmacology of the bladder. Ann. Rev. Pharmacol., I2, 197.

TANagho, E. A., Meyers, F. H. \& SMith, D. L. (I969). Urethral resistance: its components and implications. I. Smooth muscle component. Invest. Urol., 7, 136.

Thomas, D. G., Smallwood, R. \& Graham, D. (1975). Urodynamic observations following spinal trauma. Brit. F. Urol., 47, I6I.

Thorup Andersen, J., Jacobsen, O., Gammelgaard, P. A. \& Hald, T. (1976). Dysfunction of the bladder neck: a urodynamic study. Urol. Int., 31, 78.

Tramoyeres Cases, A., Valls Blasco, F. \& Tramoyeres Celma, A. (1972). The vesical neck in neurogenous bladder. Urol. Int., 27, 336.

Tulloch, A. G. S. \& Rossier, A. B. (1977). The action of neuropharmacologic agents on the bladder and urethra during experimental spinal shock. Invest. Urol., I4, 312.

VAuPEL, D. B. \& MARTIN, W. R. (I976). Actions of methoxamine and tryptamine and their interactions with cyproheptadine and phenoxybenzamine on cat spinal cord segmental reflexes. F. Pharmac. Exp. Therap., 196, 87.

Whitfield, H. N., Doyle, P. T., Mayo, M. E. \& Poopalasingham, N. (1976). The effect of adrenergic blocking drugs on outflow resistance. Br. F. Urol., 47, 823.

Yalla, S. V., Gabilondo, F. B., Blunt, K. J., Fam, B. A., Castello, A. \& Kaufman, J. M. (1977). Functional striated sphincter component at the bladder neck: clinical implications. F. Urol., II8, 408. 